\title{
Dariusz Rott
}

\section{Mapping the Early Modern World: Ptolemy's Cosmography in Sixteenth Century Cracow}

Izvorni znanstveni rad

Research paper

UDK 101:9>(438)“16/17“"

$101: 2-756>(438)$ “16/17“"

https://doi.org/10.32728/tab.17.2020.12

The stay of renowned German humanist, Conradus Celtes, in Cracow (1446-1495) most likely contributed to a shift in the development of humanist interest in geography. Laurentius Corvinus (circa 14651527), Silesian humanist and Neo-Latin poet, who between 14841494 studied and then lectured in Cracow as docens extraneus non de facultate, belonged to Celtes' circle. As a result of his lectures in Cracow, Corvinus wrote a textbook entitled Cosmographia dans manuductionem in tabulas Ptolemai [...], which was then published in Basel, in 1496. This work played an important role in developing geographical knowledge among the humanists of Cracow. It also influenced the humanist circles in Basel, Nuremberg and Tubingen, due to which teaching geography became popular in many then universities.

Key words: Laurentius Corvinus, Cracow, geography, Nicolaus Copernicus, humanism

Around 1490 Cracow saw the development of humanist interests in geography, as well as the works of Claudius Ptolemaeus (circa 100-147) and other ancient geographers. Franciszek Bujak, an expert in the history of Polish geography, wrote: „The most known sign of the new, invigorating trend in our geography, is the first Polish cosmography textbook written by a Jagiellonian 
University docent". ${ }^{1}$ What he was referring to was the textbook written by Laurentius Corvinus (Laurentius Corvinus Novoforensis, Laurentius Bartholomei De Novo Foro, Lorenz Rabe/Raabe), entitled Cosmographia. Dans manuductionem in tabulas Ptolemaei, ostendes omnes regions terrae habitales, diversa hominum genera [...], inspired by Ptolemy's thoughts and published four years after Columbus' discovery. This treatise is the first complex geographical work in Poland, ${ }^{2}$ while not an original work, full of references to ancient poets and writers, which takes great advantage of the role of ancient authorities.

The treatise was the result of Corvinus' lectures delivered in Cracow, an introduction addressed to new adepts of this scientific discipline. Before that, some chorographic motives can only be found in the writings of Gallus Anonymous and, developed into a separate literary form, in the works of Jan Długosz.

Corvinus was born around 1465 in Środa Śląska (Novum Forum, Neumarket) and died in Wrocław in $1527 .{ }^{3} \mathrm{He}$ was enrolled at the Cracow Academy in the summer term of 1448 as „Laurentius Bartholomei de Novo Foro". He was a true renaissance man: a humanist, student, and lecturer of Almae Matris Cracoviensis, a school rector in Świdnica and Wrocław, a neo-Latin poet, a philologist, a teacher, the author of a work on versification, the city secretary, a lover of Neoplatonic poetry, an erasmianist, a friend of Nicolaus Copernicus, a geographer and a wandering humanist ${ }^{4}$. He was also a member of the Sodalitas litteraria Vistulana, a literary and cultural society most likely founded by the German travelling humanist,

1 Franciszek Bujak, Geografia na Uniwersytecie Jagiellońskim, in idem, Studia geograficzno-historyczne, Kraków 1925, p. 25.

2 We should also mention the work by John of Głogów (probably Corvinus' teacher), entitled Introductorium cosmographiae. However, it does not address any chorogaphic issues. Without a doubt, Corvinus gained his basic knowledge of geography with elements of cartography and astronomy at the Cracow University.

3 For more information, see: Dariusz Rott, Wawrzyniec Korwin. Wczesnorenesansowy humanista śląski. Katowice 1997; Robert Zawadzki, Wawrzyniec Korwin - życie i twórczość renesansowego humanisty (Studium, tekst łaciński, komentarz i przekład), Częstochowa 2013. The publication also offers comprehensive and carefully compiled references (pp. 225-250).

4 Jacqueline Glomski, Patronage and Humanist Literature in the Age of the Jagiellonians. Court and Career in the Writings of Rudolf Agricola Junior, Valentin Eck, and Leonar Cox, Toronto 2007. 
poeta laureatus, Conrad Celtes (1459-1508), ${ }^{5}$ which played a significant role in shaping humanist circles in Cracow (even though it was dissolved not long after Celtes suddenly left ${ }^{6}$ the city).

Once he graduated from the Cracow Academy in 1489 Corvinus likely began lecturing as docens extraneus non de facultate on rhetoric, astronomy, philosophy and geography; ${ }^{7}$ he commented, among others, on Aristotle, Boethius and Virgil. In Cracow, he met young Nicolaus Copernicus who studied there between 1491-1494, and most likely listened to Corvinus' lectures, so that later, during his studies in Italy he could acquire up-to-date information on the discoveries of new lands. Corvinus appreciated the young, at the time unknown, astronomer, and they remained in contact during Corvinus' stay in Torun between 1506-1508. Janusz Pelc pointed out that „Corvinus and [...] Copernicus [...] showed the wide-ranging interests and versatility so typical for the renaissance people. They both were engaged in literary work and both carried out their scientific research - and their interests were wide - in order to explore the earth (geography) and the universe (astronomy)"8. At that time, Corvinus also began to write his geography textbook. His geographical interests were undoubtedly influenced by the aforementioned Conrad Celtes, poeta laureatus, the pioneer of poetic sightseeing, or regional poetry. ${ }^{9} \mathrm{He}$ introduced a very specific geographical program described as „Germania illustrata”, that is, a geographic and ethnographic-cultural description of Germany, an answer to challenges of the Renaissance age. ${ }^{10}$ Celtes was to be inspired by the work of Flavio Biondo entitled Italia illustrata. Earlier. There was to be a project, ultimately abandoned, in which Celtes would re-edit -

5 For more information see Oswald Dreyer-Eimbcke, Conrad Celtis, Humanist, Poet and Cosmographer, The Map Collector 74 (1974), pp. 18-21.

6 We do not know the reasons. Celtes himself mentions heartbreak and a large collection of books gone missing (stolen). Perhaps the reason was that he could not find a wealthy protector and had no right to lecture at the university, and could only teach privately in dorms.

7 He was most likely the first geography lecturer in Poland.

8 Janusz Pelc, Europejskość i polskość literatury naszego renesansu, Warszawa 1984, pp. 95-96.

9 Stefan Zabłocki, Beschreibung des Ostens in den Elegien von Konrad Celtis, in Landesbeschreibungen Mitteleuropas vom 15. bis 17. Jahrhundert, ed. Hans Bernd Harder, Köln-Wien 1983, pp. 141-163.

10 Wojciech Iwańczak, Do granic wyobraźni. Norymberga jako centrum wiedzy geograficznej i kartograficznej w XV i XVI wieku, Warszawa 2005, p. 66-67. The publication also provides an extensive list of references (pp. 270-303). 
in the spirit of humanism - Hartmann Shedel's famous World Chronicle published in 1493 in Latin and German. Celtes also admired Ptolemy and wrote the famous panegyric In laudes Cosmographiae Ptolemaei. He clearly stated that:

... reading the works of ancient authors should be preceded by the study of 'secrets of things', that is, works of nature described by the ancient poets. Therefore, the purpose behind studying geography which is part of this rerum natura was not to explore the real world. It was to learn only about the world presented in ancient writings. Literature should express the cosmic vision proclaimed by the Greek and Roman writers. In other words, writing about geography was strictly connected with imitatio antiquorum. ${ }^{11}$

Corvinus seems to meet this goal in his treatise.

According to Robert K. Zawadzki, who wrote Corvinus' monograph:

Without a doubt, in the capital of then Republic of Poland Corvinus was emerging - a mature and complete writer, author of works on geography, poetics, rhetoric and philosophy, who had nothing in common with any direct tradition of these disciplines in Poland ${ }^{12}$.

Corvinus left Cracow and came back to Silesia in 1494. We do not know the exact reasons for his return. Perhaps he was criticized by the defenders of scholastic philosophy at the Cracow Academy, as after the first successes of humanism between 1475-1492 there was a regress in the Academy. ${ }^{13} \mathrm{He}$ mentions this in the introduction to his Cosmography:

Et quamquam plurimos fore non dubitem, qui hoc opusculum improbaturi sunt in medium ducentes sui livoris probamentum me nondum totius Germaniae et Sarmatiae oras perlustrasse et tam repentino impetu in peregrinarum gentium errantem ${ }^{14}$ assurrexisse, quae iam maturos aevi et disertissimos decet viros, non natu minorem, qui nec dum facundos eloquii potavi latices faucesque scabrae

11 Robert Zawadzki, op. cit, p. 101.

12 Ibid., p. 63.

13 Ibid, p. 64.

Errantem corr.: errans. 
rubiginis plenas nondum cavernoso tersi pumice, eorum tamen aculeo misso facto eo iustifiam, dum quae sensu lustraverim, verum quae ab excellentissimis viris stili officio apud nos relicta sunt, scripturus sum, eadem variis poetarum sententiis comprobando. In promtu etam est neminem totam terram visurum, ob vitae cito interiturae angustiam terrarumque discrimina ex gentium discord condicione imminentia, nisi longaevi illius Nestoris superaret saeculum, a latique Pegasi insidens tergo auras traiiciat omnem telluris situm exploraturus. ${ }^{15}$

The work was printed in Basel, in $1496^{16}$, by Corvinus' student, Heinrich Bebel von lustingen, a poet and, later, professor of rhetoric in Tübingen, who also introduced the text with a special dedication. In it, he called Corvinus Sarmata doctus. ${ }^{17}$ The Cosmography was very well received, especially by German scholars and in Basel. ${ }^{18}$ The treatise was undoubtedly the fruit of Cracovian lectures delivered by Corvinus.

The Silesian humanist begins his work with the Prooemium, in which he explains the pedagogical and synthetic goal of the textbook. ${ }^{19}$ The ambitious task he set before himself was to create a textbook used by the Cracow Academy.

Within the frame of delimitation he included his most famous poem Ode Sapphica Endecasillaba, dicolos tetrastrophos Peonice de Polonia eius metropoli Cracovia in the Cosmography. ${ }^{20}$ It is a humanist praise of a beloved place in the categories of locus amoenus and laudatio urbis. Surely, Corvinus refers here to the works of his master, Celtes, praising the city of Nuremberg:

15 Cited after: Robert Zawadzki, op. cit., p. 266.

16 In the same year, Corvinus also published Carminum structura - a work reprinted many times in the years that followed.

17 Philip Melanchton called Corvinus by the same name in one of his letters.

18 It was the first polonicom printed in Basel.

19 Corvinus also discussed the content of his work in the poem preceding the Proemium entitled Penthametrum elegiacum magistri Laurentii Corvini Novoforensis in Alma Academia Cracoviensi, quo laboris sui subiectam describens materiam optimarum artium alumnus simul hortatur, ut eius operam sibi ducant commodaturam.

20 For more information see Elwira Buszkiewicz, Cracovia in litteris. Obraz Krakowa w piśmiennictwie doby Odrodzenia, Kraków 1998. 
[...] Hic sibi pulchram love nata sedem

Pallas elegit teneramque virgo

Imbuit sumni patris erudita

Dota iuventam.

Edocet formis variis solutum

Lite discordi chaos et latentis

Prima naturae peritura nullis

Semina seclis.

An dues nubesve tonent aquosae

Aeris spissi, trifidum ut iacentes

Fulmen in terras iaculatur ictu

Saepe fragoso.

Unde brumales veniunt pruinae

Et vapor largo resolutus imbri

Flabra ventorum refluaeque magni

Tethios ${ }^{21}$ aestus.

Cur situs cari22 e regione fratris

Roscidus Lunae globus it sub umbram

Saepe mortales piceam tuentes

Lampada terrens $[. . .]^{23}$.

Next, Corvinus adds another two successful poetic descriptions: Śląska (Slesiae descriptio compendiosa) and his town of birth (Pindaricum anapesticum in natale solum quo Novum Forum perhibetur).

As we know, Ptolemy's original Geography, consisting of eight books with tables and maps, is actually a comprehensive catalogue of names and geographic coordinates of places, rivers and other geographic objects. The treatise was divided into two main parts. The first section, covering mathematical and natural phenomena, included, among other things, a division of the earth into five climatic zones, a section on antipodes and explanations of Ptolemy's maps. The second, longer section included the description of the three parts of the world known at that time, and was close to chorography, that is, the regular presentation of the space (usually populated): a country, a region or a place.

21 Tethios corr.: Techios.

22 Cari corr.: chari.

Cited according to: Robert Zawadzki, op. cit., pp. 305-306. 
In general, Corvinus kept this layout and referred to one of the two main models of chorographic description, a type developed by Pomponius Mela, who viewed chorography as the description of populated areas. ${ }^{24}$ Corvinus proposed an identical structure. The first part of his treatise includes a mathematical and physical description of the Earth, consisting of about 20 pages, preceded by an introduction, and containing two poetic works by Corvinus. The second section includes the geographical description beginning with Libya, which at that time referred to Africa. Corvinus dedicated 10 pages to it, then presented Europe (31 pages) and Asia (38 pages), adding a lecture on the oceans and seas. In it, he presented a physical description of the world's regions as well as certain countries. He also provided information on plants, animals, minerals, and described the people living in each land. He also included intelligent digressions when describing, in more detail in comparison with the other lands, Italy and Greece, mentioning ancient rulers and scholars, and citing quotes from ancient writers, such as Virgil (the most quoted), Lucanus, Tibullus, Ovid, Horace, Seneca, Juvenal or Homer, which he skillfully compiled. The list is longer and includes twenty authors. He also added anecdotes, myths, ${ }^{25}$ interesting stories, ${ }^{26}$ or etymologies - information on the origin of many geographical names (this was during the initial stage of deep humanist and linguistic awareness), often drawing readers' attention according to the principle docere et delectare. This is already a visible sign of the renaissance shift in geography, of which Corvinus was one a forerunner and representative. In his treatise he also refers to other geographical writings: he mentions or quotes Strabo (over 70 times, most often when describing Greece and Asia), Solinus (about 50 times, mainly in the descriptions of Africa), Ptolemy (10 times, mainly in the first section), and, less frequently, Dionysius Periegetes, Macrobius, Pomponius Mela, Varro, and others. This is, of course, typical for geographic works of that time. Franciszek Bujak even thought that the author of the treatise expresses his critical attitude towards the ancient authorities and presents his own, independent form. At the end of the list of the treatise sources, he wrote:

24 For more information see Dariusz Rott, Staropolskie chorografie. Początki - rozwój - przemiany gatunku. Katowice 1995, passim.

25 For example, on Leto, Daedalus and Icarus, the love between Cadmus and Harmonia, etc.

26 For example, descriptions of exotic animals like elephant, crocodile, dolphin, tiger, giant ants in India, the story about Amazons, etc. 
And so, this work is in fact a compilation of Strabo and Solinus, lined with Antonius of Verona, and over a dozen of quotations from other authors, decorated again with some poetry by Virgil and Ovid. ${ }^{27}$

Once he had shared these comments, Bujak tried to characterize the author of the treatise. He did not consider him a scholar because, as he wrote, "he is a non-critical compiler and inconsistent eclecticist”. ${ }^{28} \mathrm{He}$ also did not appreciate the poetic works of Corvinus included in the treatise. Despite this, he saw some of the merits of Corvinus' work, for example ,avoidance of repeating too high numbers and extraordinary curiosities" 29 and the fact that Cosmography was the first original textbook dedicated to Polish scholars. At the end of his essay, Bujak once again evaluated the work of the Silesian humanist. This time, his opinion is more balanced:

We have already judged Corvinus' work, and it was not a favorable judgment... This work had to be evaluated as it is, as we have known it, as this was the spirit of the times. Authors referred with almost anything to the antiquity, and expected almost everything from it... Ancient works were overused but it was almost inevitable. ${ }^{30}$

The negative comments by Bujak, which may easily refer to almost any cosmographic and chorographic text of that time, determined the fate of later mentions and comments on Corvinus' treatise. In 1936, the Silesian Institute in Katowice published a short text by Bolesław Olszewicz, entitled The Oldest Geographical Descriptions of Silesia. The aim of this publication was, as we can read in the introduction, „to recognize the outstanding role Polish science had already [in the middle ages and early Renaissance - D.R.] played in the field of geography". ${ }^{31}$ In the fourth chapter, which is only two pages long, entitled Poetic Descriptions of Silesia from the Beginning of the 16th Century, Olszewicz mentions Conrad Celtes, Pancratius Vulturinus and Corvinus, offering basic biographical information on the Silesian humanist and focusing on his geographical treatise. Olszewicz wrote that the Cosmography is a „non-critical compilation, stuffed with quotations, a patchwork

27 Franciszek Bujak, op. cit., p. 30.

28 Ibid.

29 Ibid., p. 31.

30 Ibid., p. 32.

31 Bolesław Olszewicz, Najdawniejsze opisy geograficzne Śląska, Katowice 1936, p. 27. 
of excerpts from the classic authors, in which Europe is treated as it was still the province of the Roman Empire; the rest of our continent is only presented as much as one could find in ancient writings, which is not very much". ${ }^{32}$ Leokadia Matusik evaluated Corvinus' work in a slightly more gentle manner:

Compilation, like other works of this type, based primarily on Ptolemy; it did not even include - surprisingly - any mentions about the new geographical discoveries. Despite that, it contained - especially in author's free comments - many interesting and new views. ${ }^{33}$

The copy of Cosmography kept in the Sächsiche Landesbibliothek in Dresden was initially owned by Corvinus himself, who left many interesting comments in it, including hand-written remarks in Greek (proving that he knew the language). The book was then owed by Johann Hess (who died in 1547), a priest and doctor in theology, author of a lost work entitled Silesia magna, a teacher at the school near the church of Mary Magdalene in Wrocław, one of the leaders of the reformation in this city. It is interesting to note that in his large library Hess also had other important contemporary geographical works, like Tractatus de duabus Sarmatiis, Asiana et Europiana et de contess in eis written by geographer, medical doctor and rector of the Cracow Academy, Maciej of Miechów (1457-1523), published in 1517 , and for a long time the main modern source of information on Eastern Europe (Asian Sarmatia). The treatise was reprinted over twenty times in Germany, Italy and Russia.

Corvinus was a pioneer in regional geography, and he considered Silesia to be an integral part of the Polish land. His treatise initiated a dynamic development of geography at the Cracow Academy, which is proved by, among others, the works of John of Głogów ${ }^{34}$ (1445-1507), John of Stobnica (c. $1470-1519$ or 1530), and the so called Jagiellonian Globe dating from around 1510, preserved today in the Jagiellonian University Museum Collegium Maius. On the Globe,

32 Ibid.

33 Leokadia Matusik, Z dziejów nauk ścisłych na Śląsku, in Z dziejów postępowej ideologii na Śląsku w XIV - XV w., Warszawa 1956, p. 279.

34 He was likely Corvinus' lecturer. Another of his teachers was the mathematician and astronomer, Albert of Brudzewo (1446-1495). 
America is a continent distinct from that of Asia, and is already called by its proper name (America terra noviter reperta). It is one of the oldest known globes in the history of European cartography. It is also worth mentioning the sky globe by Marcin Bylica (c. 1433-1493), dating from around the mid-fifteenth century. In his last will and testament, Bylica donated it to the Cracow Academy, and Corvinus might have been familiar with it as well.

The issues of regional geography were then taken up by Bartholomaeus (Barthel) Stenus (Sthenus, Stenius) (c. 1477-c. 1523), enrolled at the Cracow Academy in 1495. He most likely listened to the lectures given by Corvinus, and perhaps they encouraged him to write Descriptio totus Silesiae et civitatis regie Vratislaviensis, an important humanistic description of Silesia, which was an excellent example of the growing interest in the landscape and topography of his region.

Stenus received his baccalaureate in Cracow in 1498, and three years later was granted the title of magister in philosophy - magisterium in artibus. He then soon left for Wrocław where he most likely remained in contact with Corvinus. He also studied medicine at the University of Vienna and in winter term of 1506, he lectured on the works of Aristotle and Cicero in Cracow. In the fall of 1508, he moved to the University of Wittenberg where, after a while, he became the head of the institute of mathematics and geography. He was the first geography teacher at German universities known to us.

Henryk Barycz, who discussed the development of geography in the age of the Renaissance, noticed that Cracow contributed greatly the development of this discipline, saying that:

the merit of the geography-focued circles in the Cracow university was not only quick assimilation and consistent adaptation of new geographical achievements, introducing them in the scientific works, new ways of approaching these issues and focusing on the surrounding reality, but also wide-spread influence outside the academy. This academic, geography hub impacted the thoughts of such innovators of earth sciences like C. Celtes, H. Bebel, J. Aventinus, B. Sthen, J. Werner and others. ${ }^{35}$

35 Henryk Barycz, Rozwój nauki w Polsce w dobie Odrodzenia, in Odrodzenie w Polsce. Materiały sesji naukowej PAN, vol. 2: Historia nauki, part. 1, Warszawa 1956, p. 125. 
Corvinus' textbook, like the commentary to Ptolemy's Geography by John of Głogów (Glogoviensis) (1445-1507) and Introduction to Ptolemy's Cosmography by John of Stobnica (c. $1470-1519$ or 1530), confirms that the Latin translation of this text quickly arrived in Cracow and was used creatively in the local academic environment.

Corvinus' work played an important role in developing geographical knowledge (combined with his cognitive curiosity: interest in astronomy, mathematics, cartography, humanist culture, print and book trade) among the humanists of Cracow. It also influenced the humanist circles in Basel, Nuremberg and Tubingen. Corvinus, called Sarmata doctus by his contemporaries, was the forerunner of regional geography, the first geography teacher in Poland, and his textbook, even though it was - according to the principle of imitatio antiquorum - a compilation of ancient texts, burdened by the ancient tradition and the authority of Ptolemy and, to a lesser degree, Strabo, ${ }^{36}$ had influenced humanist circles, especiaIly in Wrocław and Nuremberg. An aspect of this that is very interesting and worth further study is that of how the image of the world, the value of space, and reflection on geographical discoveries were shaped in the spatial images and mentality of contemporary intellectual circles.

After the publication of Maciej of Miechów's famous work Tractatus de duabus Sarmatiis, Asiana et Europiana, Corvinus' death and the end of the Copernican period, the Cracow Academy experienced a regress and decline in academic geography. ${ }^{37}$ It had never become the centre of geography, cartography, mathematics and astronomy like the Nuremberg school did at the end of the 15th and the first half of the 16 th century. ${ }^{38}$

36 Aubrey Diller, The Textual Tradition of Strabo's Geography, Amsterdam 1975.

37 A similar regress was noted in the second half of the 16th century in Nuremberg and all off Germany, and geography began to develop in the Netherlands, especially in Antwerp and Amsterdam. See Wojciech Iwańczak, op. cit., pp. 268-269.

38 Ibid.; Gerald Straus, Nuremberg in the sixteenth century, New York-London-Sydney 1966. 


\section{BIBLIOGRAPHY}

\section{BARYCZ 1956}

Henryk Barycz, Rozwój nauki w Polsce w dobie Odrodzenia, in Odrodzenie w Polsce. Materiały sesji naukowej PAN, vol. 2: Historia nauki, part. 1, Warszawa 1956.

\section{BUJAK 1925}

Franciszek Bujak, Geografia na Uniwersytecie Jagiellońskim, in idem, Studia geograficzno-historyczne, Kraków 1925.

\section{BUSZKIEWICZ 1998}

Elwira Buszkiewicz, Cracovia in litteris. Obraz Krakowa w piśmiennictwie doby Odrodzenia, Kraków 1998.

\section{DILLER 1975}

Aubrey Diller, The Textual Tradition of Strabo's Geography, Amsterdam 1975.

\section{DREYER-EIMBCKE 1974}

Oswald Dreyer-Eimbcke, Conrad Celtis, Humanist, Poet and Cosmographer, The Map Collector 74 (1974), pp. 18-21.

\section{GLOMSKI 2007}

Jacqueline Glomski, Patronage and Humanist Literature in the Age of the Jagiellonians. Court and Career in the Writings o Rudolf Agricola Junior, Valentin Eck, and Leonar Cox, Toronto 2007.

IWAŃCZAK 2005

Wojciech Iwańczak, Do granic wyobraźni. Norymberga jako centrum wiedzy geograficznej i kartograficznej w XV i XVI wieku, Warszawa 2005.

\section{MATUSIK 1956}

Leokadia Matusik, Z dziejów nauk ścisłych na Śląsku, in Z dziejów postępowej ideologii na Śląsku w XIV - XV w., Warszawa 1956.

OLSZEWICZ 1936

Bolesław Olszewicz, Najdawniejsze opisy geograficzne Śląska, Katowice 1936.

\section{PELC 1984}

Janusz Pelc, Europejskość i polskość literatury naszego renesansu, Warszawa 1984, pp. 95-96.

\section{ROTT 1995}

Dariusz Rott, Staropolskie chorografie. Początki - rozwój - przemiany gatunku, Katowice 1995.

\section{ROTT 1997}

Dariusz Rott, Wawrzyniec Korwin. Wczesnorenesansowy humanista śląski, Katowice 1997. 


\section{STRAUS 1966}

Gerald Straus, Nuremberg in the sixteenth century, New York-London-Sydney 1966.

\section{ZABŁOCKI 1983}

Stefan Zabłocki, Beschreibung des Ostens in den Elegien von Konrad Celtis, in Landesbeschreibungen Mitteleuropas vom 15. bis 17. Jahrhundert, ed. Hans Bernd Harder, Köln-Wien 1983, pp. 141-163.

\section{ZAWADZKI 2013}

Robert Zawadzki, Wawrzyniec Korwin - życie i twórczość renesansowego humanisty (Studium, tekst łaciński, komentarz i przekład), Częstochowa 2013. 


\section{SUMMARY}

Mapping the Early Modern World: Ptolemy's Cosmography in Sixteenth Century Cracow

Around 1490 Cracow saw the development of humanist interests in geography, as well as in the works of Claudius Ptolemaeus (circa 100-147) and other ancient geographers. The stay of the renown German humanist, Conradus Celtes, in Cracow (1446-1495) most likely contributed to this shift. Laurentius Corvinus (circa 14651527), Silesian humanist and Neo-Latin poet, who between 14841494 studied and then lectured in Cracow as docens extraneus non de facultate (his lectures were attended by, for example, young Nicolaus Copernicus), belonged to Celtes' circle. As a result of his lectures in Cracow, Corvinus wrote the textbook entitled Cosmographia dans nanuductionem in tabulas Ptolemai [...], which was then published in Basel, in 1496. This paper presents the main facts concerning Corvinus' life and discusses the content of his work. It also presents the circles of contemporary Renaissance humanists in Cracow, in particular scholars of geography and astronomy. This work played an important role in developing geographical knowledge among the humanists of Cracow. It also influenced humanist circles in Basel, Nuremberg and Tubingen. Today, Corvinus' Cosmographia is a rather forgotten work, not often analyzed by researchers of the history of Polish geography and historians of older literature. 


\section{SAŽETAK}

\section{Mapiranje svijeta u ranome novom vijeku. Ptolemejeva} Kozmografija u Krakovu u 16. stoljeću

Oko 1490. godine Krakov je bio mjesto pojačanoga humanističkog zanimanja za geografiju, pa tako i za djela Klaudija Ptolemeja (oko 100. - 147.) i drugih antičkih geografa. Tomu je najvjerojatnije pridonio i boravak znamenitoga njemačkog humanista Konrada Celtesa (1446. 1495.) u Krakovu. Njegovu je intelektualnom krugu pripadao i Laurencije Korvin (oko 1465. - 1527.) , šleski humanist i novolatinski pjesnik koji je 1484. - 1494. studirao, a zatim i predavao u Krakovu kao docens extraneus non de facultate (njegova je predavanja pohađao i, primjerice, mladi Nikola Kopernik). Korvin je, kao rezultat svojih krakovskih predavanja, napisao udžbenik Cosmographia dans nanuductionem in tabulas Ptolemai, tiskan u Baselu 1496. U članku se predstavljaju najvažnije činjenice iz Korvinova života te se raspravlja o sadržaju njegova djela, a prikazuju se i intelektualni humanistički krugovi onodobnog renesansnog Krakova, osobito oni učenjaka geografa i astronoma. Korvinovo je djelo značajno utjecalo na razvoj geografskoga znanja krakovskih humanista, kao i na humanističke intelektualne krugove u Baselu, Nürnbergu i Tübingenu. Danas je njegova Cosmographia uglavnom zaboravljeno djelo, a istraživači povijesti poljske geografije i povjesničari književnosti njime se slabo bave.

Ključne riječi: Laurencije Korvin, Krakov, geografija, Nikola Kopernik, humanizam 